\title{
Komparatif Kinerja Dosen yang Bersertifikasi Pada Universitas Swasta di Seberang Ulu Kota Palembang
}

\author{
Nisa' Ulul Mafra, \\ Fakultas Ekonomi, Universitas PGRI Palembang \\ Email:nisaulul29@gmail.com \\ Tri Sinarti \\ Fakultas Ekonomi, Universitas PGRI Palembang, \\ Email :trisinarti1976@gmail.com
}

\begin{abstract}
This study aims to compare and find out whether there are differences in the performance of certified lecturers at private universities in Seberang Ulu, Palembang. The population in this study were 325 respondents. While the sample used by using Slovin calculation is 76 respondents, with random sampling analysis technique. The analysis model used is the Analysis of Variance Test (ANOVA). The results obtained after testing it is known there are significant differences in the average performance of certified lecturers at the Private Universities.
\end{abstract}

Keywords: Lecturer perfomance

\begin{abstract}
Abstrak
Penelitian ini bertujuan untuk membandingkan s ekaligus mengetahui adakah perbedaan kinerja dosen yang bersertifikasi pada universitas Swasta di Seberang Ulu Kota Palembang. Populasi pada penelitian ini sebanyak 325 responden. Sedangkan s ampel yang digunakan dengan memakai perhitungan Slovin adalah 76 responden, dengan teknik analis is random sampling. Model analis is yang digunakan adalah Uji Analys is of Variance (ANOVA). Hasil yang diperoleh setelah pengujian diketahui ada perbedaan rata-rata secara signifikan kinerja dosen yang bersertifikasi pada Universitas Swasta tersebut.
\end{abstract}

Kata Kunci: Kinerja dosen

\section{Pendahuluan}

Sebagaimana disebutkan dalam Garis-garis Besar Haluan Negara tahun 1999, bahwa perguruan tinggi swasta sebagai mitra perguruan tinggi negeri dan merupakan bagian dari sistem pendidikan nasional perlu terus didorong untuk meningkatkan pertumbuhan, peranan, tanggung jawab dan mutu pendidikan dengan tetap mengindahkan ciri khas perguruan tinggi swasta yang bersangkutan serta syarat-syarat pendidikan secara umum (Trisnaningsih,2011). Hal ini berarti bahwa perguruan tinggi harus memperkuat kemampuan jajaran/civitas akademika supaya lebih profesional dan berkualitas.

Salah satu unsur penting dalam barisan perguruan tinggi yang berperan dalam pembangunan nasional sebagai agen perubahan di bidang pendidikan adalah dosen. Mengingat pentingnya peranan dosen dalam proses menciptakan sumber daya manusia yang berkualitas terutama untuk peningkatan kualitas bagi mahasiswa, maka dosen yang akan mengajar harus memiliki beberapa persyaratan yang telah ditentukan oleh undangundang. Undang-Undang Nomor 14 Tahun 2005 tentang Guru dan Dosen pasal 45, menyatakan bahwa seorang dosen wajib memiliki kualifikasi akademik, kompetensi, sertifikat pendidik, sehat jasmani dan rohani, dan memenuhi kualifikasi lain yang 
dipersyaratkan satuan pendidikan tinggi tempat bertugas, serta memiliki kemampuan untuk mewujudkan tujuan pendidikan nasional.

Masih menurut Undang-Undang yang sama, menyatakan dosen juga dituntut memiliki empat kompetensi dalam mengemban tugas Tridharma Perguruan Tinggi. Keempat kompetensi tersebut meliputi pedagogik, profesional, kepribadian dan sosial. Kompetensi sebagai karakteristik yang mendasar yang dimiliki seseorang yang berpengaruh langsung terhadap, atau dapat memprediksikan kinerja yang sangat baik (McClelland dalam Rivai dan Sagala,2011).

Menurut UU Nomor 14 Tahun 2005 tentang Guru dan Dosen, Undang-undang nomor 12 tahun 2012 tentang Pendidikan Tinggidan Peraturan Pemerintah Republik Indonesia Nomor 37 Tahun 2009 tentang Dosen menyatakan dosen adalah pendidik profesional dan ilmuwan dengan tugas utama mentransformasikan, mengembangkan, dan menyebarluaskan ilmu pengetahuan, teknologi, dan seni melalui pendidikan, penelitian, dan pengabdian kepada masyarakat. Lebih lanjut pada Pasal 60 ayat 1 Undang-Undang tersebut dicantumkan bahwa dalam melaksanakan tugas keprofesionalan, dosen berkewajiban melaksanakan pendidikan, penelitian dan pengabdian pada masyarakat sedangkan ayat 2 dicantumkan bahwa dosen juga berkewajiban merencanakan, melaksanakan proses pembelajaran, menilai dan mengevaluasi pembelajaran.

Sejalan dengan hal tersebut dosen dituntut untuk mampu mengembangkan Tri Dharma Perguruan Tingginya melalui kegiatan pendidikan/pengajaran, penelitian dan pengabdian pada masyarakat. Peningkatan kualitas dosen di bidang Tri Dharma Perguruan Tinggi terus diupayakan pemerintah salah satunya dengan pemberian sertifikasi sebagai penghargaan atas kinerja dosen.Tujuan pemberian sertifikasi pendidik bagi dosen diharapkan dapat memotivasi dosen sehingga dapat meningkatkan kompetensinya yang tercermin dari kinerjanya melalui pelaporan Beban Kerja Dosen (BKD).

Permen 47 tahun 2009 menyatakan bahwa sertifikasi dosen adalah pemberian sertifikat pendidik untuk dosen melalui uji kompetensi untuk mendapatkan sertifikat pendidik. Uji kompetensi dilakukan melalui penilaian dokumentasi portofolio yang merepresentasikan kualifikasi akademik dan unjuk kerja Tri Dharma Perguruan Tinggi. Dengan melihat kompleksitas penilaian sertifikasi dosen, seorang dosen yang telah lulus sertifikasi dosen dapat diasumsikan telah memiliki kualitas profesionalisme dosen sehingga kepada dosen yang telah memiliki sertifikat pendidik akan mendapatkan tunjangan profesi dosen sesuai dengan ketentuan peraturan perundang-undangan (UU No.14 tahun 2005 pasal 53 tentang guru dan dosen).

Peran, tugas, dan tanggung jawab dosen sangat bermakna dalam mewujudkan tujuan pendidikan nasional, yaitu mencerdaskan kehidupan bangsa, meningkatkan kualitas manusia Indonesia, meliputi kualitas iman dan takwa, akhlak mulia,dan penguasaan ilmu pengetahuan, teknologi, dan seni, serta mewujudkan masyarakat Indonesia yang maju, adil, makmur, dan beradab. Untuk melaksanakan fungsi, peran dan kedudukanyang sangat strategis tersebut diperlukan dosen yang profesional. Penguasaan terhadap materi menjadi salah satu prasyarat untuk melaksanakan pembelajaran yang efektif, karena dosen juga menjadi sumber pengetahuan bagi mahasiswa. 
Berdasarkan survey sementara yang dilakukan bahwa kinerja dosen sebagai ujung tombak peningkatan kualitas pendidikan menunjukkan kerja yang belum optimal, hal ini dapat dilihat dari pelaksanaan Tri Dharma Perguruan Tinggi yang harus dilakukan dosen tetapi masih ada dosen yang kurang berkonsentrasi secara penuh terhadap tugasnya termasuk membuat persiapan mengajar seperti bahan ajar/diktat dan RPS, atau dosen datang terlambat dalam proses belajar mengajar bahkan tidak melaksanakan tugas belajar mengajar dikelas dengan banyak alasan, kurangnya pengabdian pada masyarakat yang harus dilaksanakan oleh dosen setiap semester baik secara mandiri ataupun didanai oleh Universitas, masih sedikitnya penelitian mandiri atau kelompok yang dilakukan, kurangnya dosen yang terlibat dalam penulisan jurnal ilmiah ataupun artikel ilmiah baik yang dipublikasikan ataupun yang tidak dipublikasikan. Tri Dharma Perguruan Tinggi ini harus dilakukan karena sebagai syarat kecukupan pemenuhan kebutuhan angka kredit dengan minimal 12 SKS dan Maksimal 16 SKS sebagai pelaporan kinerja dosen dalam Beban Kerja Dosen (BKD).

Penelitian ini bertujuan untuk mengetahui kinerja dosen setelah lulus sertifikasi dosen dan mendapat tunjangan pofesi serta untuk mengetahui apakah ada perbedaan kinerja dosen yang bersertifikasi pada Universitas Swasta di Seberang Ulu Kota Palembang. Permasalahan dalam penelitian ini adalah kinerja dosen pada Universitas Swasta di Seberang Ulu Kota Palembang dalam pelaksanaan Tri Darma Perguruan Tinggiyang perlu ditingkatkan lagi. Berdasarkan kondisi di atas, muncul keinginan peneliti untuk mengkomparasi kinerja dosen yang bersertifikasi pada Universitas Swasta di Seberang Ulu Kota Palembang.

\section{Literature Review}

Tujuan atau target pencapaian merupakan hal yang sangat penting untuk mengukur suatu kinerja. Kinerja dapat diketahui dan diukur jika individu atau kelompok karyawan dalam hal ini dosen telah mempunyai kriteria atau standar keberhasilan tolak ukur yang ditetapkan. Oleh karena itu, perlu ditetapkan standar kinerja untuk mengetahui keberhasilan kerja.

Wibowo (2014) kinerja berasal dari pengertian performance. Ada pula yang memberikan pengertian permormance sebagai hasil kerja atau prestasi kerja. Namun, sebenarnya kinerja mempunyai makna yang lebih luas, bukan hanya hasil kerja, tetapi termasuk bagaimana proses pekerjaan berlangsung.

Mangkunegara (2011) prestasi kerja berasal dari kata job performance atau actual performance, yaitu hasil kerja secara kualitas dan kuantitas yang dicapai oleh seorang pegawai dalam melaksanakan tugasnya sesuai dengan tanggung jawab yang diberikan kepadanya. Kinerja dosen merupakan salah satu faktor penentu keberhasilan proses belajar mengajar diperguruan tinggi.

Selanjutnya kinerja adalah hasil pekerjaan yang dicapai seseorang atau kelompok seperti standar hasil kerja, target yang ditentukan selama periode tertentu yang berpedoman pada norma, standar operasional prosedur, kriteria dan fungsi yang telah ditetapkan atau yang berlaku dalam perusahaan (Bangun, 2012) 
Menurut Undang-Undang No. 12 Tahun 2012, Pasal 1 Ayat 9 tentang Tridharma Perguruan Tinggi adalah kewajiban Perguruan Tinggi untuk menyelenggarakan (1) Pendidikan, (2) Penelitian, dan (3) Pengabdian kepada masyarakat dan sekaligus sebagai kewajiban dosen dalam pencapaian kinerja dosen.

Ada beberapa peneliti telah meneliti tentang kinerja dosen yang bersertifikasi, seperti yang dilakukan Mafra, dkk (2018), Suhada, dkk (2017), dan Gadeng (2014), yang menyimpulkan bahwa kinerja dosen akan meningkat jika lulus sertifikasi dosen. Penelitian lain yang dilakukan oleh Fauziah, dkk (2017) tentang analisis perbandingan kinerja pegawai.

\section{Metodologi Penelitian}

Lokasi Penelitian ini dilakukan pada Universitas Swasta di Seberang Ulu Kota Palembang, Sumatera Selatan dengan objek penelitian Universitas PGRI Palembang (UPGRI Palembang), Universitas Muhammadiyah Palembang (UMP) dan Universitas Bina Darma (Bidar). Dalam penelitian ini peneliti menggunakan metode penelitian kuantitatif. Menurut Sugiyono (2017) metode penelitian kuantitatif dapat diartikan sebagai metode penelitian yang berlandaskan pada filsafat positivisme, digunakan untuk meneliti pada populasi atau sampel tertentu, pengumpulan data menggunakan instrumen penelitian, analisis data bersifat kuantitatif/statistik dengan tujuan untuk menguji hipotesis yang telah ditetapkan.

Populasi dalam penelitian ini adalah dosen tetap yang telah memperoleh sertifikasi pada Universitas Swasta Seberang Ulu kota Palembang berjumlah 325 orang dosen dan teknik pengambilan sampel dalam penelitian ini memakai proportional random sampling karena anggota populasi dianggap homogen dan pengambilan sampel anggota populasi dilakukan secara acak tanpa memperhatikan strata yang ada dalam populasi tersebut (Sugiyono, 2017). Penentuan jumlah sampel dari populasi tertentu yang dikembangkan dari Slovin (Umar. 2010). Jadi jumlah sampel dalam penelitian ini dengan menggunakan rumus tersebut diperoleh sampel sebanyak 76 responden.

Metode pengumpulan data yang digunakan untuk memperoleh data dalam penelitian ini adalah field reseach atau studi lapangan, yaitu penelitian yang dilakukan secara langsung dengan membagikan kuesioner kepada responden yang dianggap memenuhi syarat. Sumber data yang digunakan adalah data primer dikumpulkan melalui kuesioner yang dibagikan pada responden. Kuesioner ini digunakan untuk mengukur kinerja dosen dengan menggunakan pengukuran skala Likert.

Model analisis yang digunakan untuk mengolah hasil penelitian guna memperoleh suatu kesimpulan dalam instrumen adalah Uji Analysis of Variance (ANOVA).Uji ini digunakan untuk menguji hubungan antara satu variabel dependen (skala metrik) dengan satu atau lebih variabel independen (skala nonmetrik atau kategorikal dengan kategori lebih dari dua) (Ghozali, 2005 dalam Aditya, 2011). Uji statistik yang digunakan adalah uji statistik parametrik One Way Anova jika datanya homogen. Alternatif kedua jika data yang digunakan tidak homogen maka pengujian dilanjutkan dengan menggunakan uji non parametrik Kruskal Wallis. 


\section{Hasil dan Pembahasan}

\section{Uji Validitas dan Uji Reliabiltas}

Untuk uji validitas dari variabel kinerja diperoleh nilai rhitungyaitu $(0,491 \mathrm{~s} / \mathrm{d} \quad 0,762)$, karena nilai rhitung lebih besar dari $r_{t a b e l}(0,2257)$ maka seluruh pertanyaan variabel tersebut dinyatakan valid. Sedangkan untuk uji reliabilitas diperoleh nilai sebesar 0,845 yangmempunyai koefisien Alpha diatas 0,6 sehingga dapat dikatakan bahwa kuesioner yang digunakan dalam penelitian ini merupakan kuesioner yang handal (reliabel).

\section{Uji Asumsi Klasik}

Pada uji normalitas data menggunakan One Sample Kolmogorov Smirnov Test, dapat disimpulkan bahwa semua variabel berdistribusi normal, hal tersebut dikarenakan data tersebut memiliki Asymp. Sig $(0,147>(\alpha)$ 0,05 sehingga dapat digunakan untuk analisis selanjutnya.Uji homogenitas digunakan untuk mengetahui apakah beberapa varian populasi adalah sama atau tidak. Uji ini dilakukan sebagai prasyarat dalam analisis independent sample $t$ test dan ANOVA. Asumsi yang mendasari dalam analisis varian (ANOVA) adalah bahwa varian dari populasi adalah sama. Berdasarkan hasil pengujian homogenitas diperoleh nilai sig sebesar 0,179>0,05 yang berarti varian kelompok kinerja dosen yang dibandingkan adalah sama (homogen).

\section{Data Statistik Deskriptif}

Statistik deskriptif memberikan gambaran tentang nilai minimum, maksimum, rata-rata dan standar deviasi tentang masing-masing kinerja dosen setiap universitas dalam penelitian ini. Di bawah ini data statistik yang telah lulus uji asumsi klasik yaitu homogenitas.

Tabel 1. Analisis Descriptives: Kinerja Dosen

Kinerja Dosen

\begin{tabular}{|l|r|r|r|r|r|r|}
\hline & $\mathrm{N}$ & \multicolumn{1}{c|}{ Mean } & \multicolumn{1}{c|}{ Std. Deviation } & \multicolumn{1}{c|}{ Std. Error } & Minimum & \multicolumn{1}{c|}{ Maximum } \\
\hline Bidar & 21 & 38.14 & 4.757 & 1.038 & 28 & 45 \\
PGRI & 18 & 37.50 & 3.073 & .724 & 34 & 45 \\
UMP & 37 & 35.62 & 3.353 & .551 & 31 & 45 \\
Total & 76 & 36.76 & 3.857 & .442 & 28 & 45 \\
\hline
\end{tabular}

Sumber : Data primer yang diolah 2019

Berdasarkan tabel diatas, Universitas Bina Darma (Bidar) memiliki rata-rata sebesar 38,14 dengan nilai minimum dan maksimum sebesar 28 dan 45. Sedangkan standar deviasi (simpangan baku) sebesar 4,757 menunjukkan variance atau kesenjangan yang cukup besar. Hal ini menunjukkan bahwa rata-rata kinerja dosen yang dimiliki oleh Bidar paling rendah $0 \%$ dan paling tinggi $100 \%$ dengan rata-rata sebesar $38 \%$. Univ. PGRI Palembang (UPGRI Palembang) memiliki rata-rata sebesar 37,50 dengan nilai minimum dan maksimum sebesar 34 dan 45. Sedangkan simpangan baku sebesar 3,073 menunjukkan variance atau kesenjangan yang cukup besar. Hal ini menunjukkan bahwa rata-rata kinerja dosen yang dimiliki oleh UPGRI Palembang paling rendah 0\% dan paling tinggi $100 \%$ dengan rata-rata sebesar 37- 38\%. Universitas Muhammadiyah Palembang (UMP) memiliki rata-rata sebesar 35,62 dengan nilai minimum dan 
maksimum sebesar 31 dan 45. Sedangkan simpangan baku sebesar 3,353 menunjukkan variance atau kesenjangan yang cukup besar. Hal ini menunjukkan bahwa rata-rata kinerja dosen yang dimiliki oleh UMP paling rendah 0\% dan paling tinggi $100 \%$ dengan rata-rata sebesar $36-37 \%$.

\section{Uji Analysis Of Variance (ANOVA)}

Berikut hasil analisis ANOVA tentang variabel kinerja dosen

Tabel 2. Uji Oneway ANOVA

Kinerja Dosen

\begin{tabular}{|l|r|r|r|r|r|}
\hline & Sum of Squares & Df & Mean Square & F & Sig. \\
\hline Between Groups & 97.963 & 2 & 48.981 & 3.513 & .035 \\
Within Groups & 1017.774 & 73 & 13.942 & & \\
Total & 1115.737 & 75 & & & \\
\hline
\end{tabular}

Sumber : Data primer yang diolah 2019

Berdasarkan output ANOVA diatas diketahui $F_{\text {hitung }}$ 3,513 $>F_{\text {tabel }}$ 3,13 dan nilai Sig sebesar 0,035<0,05 sehingga dapat disimpulkan bahwa kinerja dosen ketiga Universitas Swasta tersebut (Univ. Bina Darma, Univ. PGRI Palembang dan Univ. Muhammadiyah Palembang) ada perbedaan rata-rata secara signifikan.

Tabel 3. Post Hoc Tests

Multiple Comparisons

Dependent Variable:Perbedaan Kinerja Dosen

\begin{tabular}{|c|c|c|c|c|c|c|c|}
\hline & \multirow{2}{*}{$\begin{array}{c}\text { (I) } \\
\text { Universitas }\end{array}$} & \multirow{2}{*}{$\begin{array}{c}\mathrm{J}) \\
\text { Universitas }\end{array}$} & \multirow{2}{*}{$\begin{array}{c}\text { Mean } \\
\text { Difference (I- } \\
\mathrm{J})\end{array}$} & \multirow{2}{*}{$\begin{array}{l}\text { Std. } \\
\text { Error }\end{array}$} & \multirow[t]{2}{*}{ Sig. } & \multicolumn{2}{|c|}{ 95\% Confidence Interval } \\
\hline & & & & & & $\begin{array}{l}\text { Lower } \\
\text { Bound }\end{array}$ & $\begin{array}{l}\text { Upper } \\
\text { Bound }\end{array}$ \\
\hline \multirow{8}{*}{ LSD } & \multirow{2}{*}{ Bidar } & PGRI & .643 & 1.199 & .594 & -1.75 & 3.03 \\
\hline & & UMP & $2.521^{*}$ & 1.020 & .016 & .49 & 4.55 \\
\hline & \multirow{2}{*}{ PGRI } & Bidar & -.643 & 1.199 & .594 & -3.03 & 1.75 \\
\hline & & UMP & 1.878 & 1.073 & .084 & -.26 & 4.02 \\
\hline & \multirow{2}{*}{ UMP } & Bidar & $-2.521^{*}$ & 1.020 & .016 & -4.55 & -.49 \\
\hline & & PGRI & -1.878 & 1.073 & .084 & -4.02 & .26 \\
\hline & \multirow{2}{*}{ Bidar } & PGRI & .643 & 1.199 & 1.000 & -2.30 & 3.58 \\
\hline & & UMP & $2.521^{*}$ & 1.020 & .047 & .02 & 5.02 \\
\hline \multirow{4}{*}{ Bonferroni } & \multirow{2}{*}{ PGRI } & Bidar & -.643 & 1.199 & 1.000 & -3.58 & 2.30 \\
\hline & & UMP & 1.878 & 1.073 & .253 & -.75 & 4.51 \\
\hline & \multirow{2}{*}{ UMP } & Bidar & $-2.521^{*}$ & 1.020 & .047 & -5.02 & -.02 \\
\hline & & PGRI & -1.878 & 1.073 & .253 & -4.51 & .75 \\
\hline
\end{tabular}

*. The mean difference is significant at the 0.05 level.

Sumber : Data primer yang diolah 2019

Berdasarkan tabel uji Post Hoc baik dengan LSD maupun Bonferroni diketahui ada perbedaan rata-rata yang signifikan. Mean Bidar berbeda sinifikan dengan UMP (2.521) dengan tingkat signifikan 0,016. Mean PGRI tidak berbeda dengan UMP (1.878) dengan tingkat signifikan 0,84 dan mean UMP berbeda signifikan dengan Bidar (-2.521) tingkat signifikan 0,016 dengan tetapi Bidar tidak berbeda dengan PGRI (-1.878) tingkat signifikan 0,84 . 
Dari hasil uji ANOVA diketahui bahwa terdapat perbedaan rata-rata antara kinerja dosen pada ketiga Universitas Swasta yang terdapat di Seberang Ulu Kota Palembang walaupun tidak terlalu besar. Sedangkan dari data statistik deskriptif pada tabel 1 diketahui rata-rata kinerja dosen ditempati oleh Bidar, sedangkan rata-rata kinerja dosen yang kedua ditempati oleh UPGRI Palembang dan yang terakhir rata-rata kinerja ditempati oleh UMP. Dengan demikian secara deskriptif bahwa rata-rata kinerja dosen paling tinggi adalah kinerja dosen di Universitas Bina Darma yaitu sebesar 38,14 (38,14\%). Tabel 2 menunjukkan uji $\mathrm{F}$ lebih besar dari $\mathrm{F}$ tabel yang berarti bahwa ada perbedaan kinerja ketiga universitas swasta di seberang Ulu Kota Palembang.

Sedangkan untuk detailnya dapat diketahui pada uji Post Hoc Test. Pada tabel 3 menunjukkan hanya pada mean Bidar berbeda signifikan dengan UMP, tetapi mean Bidar tidak berbeda dengan UPGRI Palembang. Mean UMP tidak beda dengan UPGRI Palembang tetapi berbeda dengan Bina Darma.

Dari hasil inipun dapat dilihat bahwa perbedaan kinerja dosen pada masing-masing universitas tidak terlalu terjauh. Jika nilai terendah adalah $0 \%$ dan tertinggi adalah $100 \%$ maka hasil yang diperolehpun belum cukup besar.

Keadaan ini menunjukkan bahwa kinerja dosen yang bersertifikasi belum maksimal dan masih harus terus ditingkatkan. Seperti lebih disiplin dan bertanggung jawab terhadap kelas. Pada penelitian, setiap dosen harus memiliki kemandirian dan memperluas scope penelitian dan dari segi dana bukan hanya memperoleh bantuan dari universitas saja tetapi dapat melalui pemerintah atau bahkan swasta. Tetapi juga ikut dalam jurnal internasional. Artinya dosen diminta memperbanyak kuantitas penelitian sekaligus meningkatkan kualitas penelitian. Sedangkan untuk pengabdian pada masyarakat (PKM), perlu lebih banyak melakukannya dan bukan hanya pada setiap semester saja.

Hal yang terpenting dari semua ini adalah substansinya bukan hanya sekedar berorientasi pada pemenuhan administratif semata atau untuk memenuhi laporan Beban Kerja Dosen (BKD) tetapi setiap dosen sadar akan tanggung jawab profesi. Pemberian tunjangan profesi dalam hal ini sertifikasi dosen dari pemerintah mempunyai tujuan agar dosen yang bersangkutan dapat meningkatkan kinerjanya sebagai bentuk tanggung jawab moral atas kepercayaan yang diberikan kepada setiap dosen yang dinyatakan lulus dalam sertifikasi dosen (serdos).

Penelitian tentang kinerja dosen oleh Gadeng (2014) yang membuktikan kompetensi dosen akan berpengaruh pada kinerjanya. Selanjutnya penelitian tentang kinerja dosen yang telah bersertifikasi pernah dilakukan oleh Mafra, dkk (2018) dan Suhada, dkk (2017) yang menunjukkan bahwa dosen yang bersertifikasi akan lebih giat untuk meningkatkan kinerja sebagai tolak ukur dalam penilaian beban kerja dosen (BKD). Hal ini membuktikan bahwa sertifikasi dosen sangat berpengaruh terhadap kinerja dosen.

Sedangkan penelitian mengenai perbandingan kinerja pegawai yang dilakukan oleh Fauziah, dkk (2016) dengan judul analisis perbandingan kinerja pegawai di kantor camat kabupaten rokan hulu (studi kasus kantor Camat Tambusai dan kantor Camat Rambah) menunjukkan bahwa tidak terdapat perbedaan kinerja pegawai pada kedua kantor camat 
tersebut. Walaupun bahasan tidak sama tetapi intinya adalah untuk membandingkan kinerja pada dua objek yang berbeda. Hasil yang didapatpun berbeda. Pada penelitian ini hasil yang diperoleh menunjukkan terdapat perbedaan yang signifikan pada kinerja dosen yang bersertifikasi pada ketiga Universitas Swasta di Kota Palembang.

\section{Simpulan}

Berdasarkan hasil analisis dan pengujian dapat ditarik kesimpulan bahwa ada perbedaan rata-rata (mean) secara signifikan antara kinerja dosen yang bersertifikasi pada Universitas Swasta di Seberang Ulu Kota Palembang terutama antara Bina Darma dengan Universitas Muhammadiyah Palembang. Walaupun antara Bidar dengan UPGRI Palembang tidak berbeda, juga antara UMP dengan UPGRI Palembang. Idealnya, tidak ada perbedaan kinerja dosen yang bersertifikasi karena dosen tersebut sudah terukur tingkat profesionalitasnya dimanapun mereka bertugas. Dikarenakan kewajibannya sama yaitu setiap dosen harus melaporkan kinerjanya pada setiap semester yang mencakup Tri Dharma Perguruan Tinggi, seperti Pendidikan dan Pengajaran, Penelitian dan Pengabdian pada Masyarakat.

\section{Daftar Pustaka}

Bangun, W. (2012). Manajemen Sumber Daya Manusia. Jakarta: Erlangga.

Fauziah, Makmur dan Andi Afrizal. (2017). Analisis Perbandingan Kinerja Pegawai di Kantor Camat Kabupaten Rokan Hulu (Studi Kasus Kantor Camat Tambusai dan Kantor Camat Rambah). e-journal Mahasiswa Fakultas Ekonomi Universitas Pasir Pengaraian, 4 (1). Diunduh dari: e-journal.upp.id/index.php/fekon/article/viem/1192.

Gadeng, Tarmizi. (2014). Pengaruh Kompetensi Terhadap Kinerja Dosen Universitas Muhammadiyah Aceh. Jurnal Akuntansi Muhammadiyah, 1.4 (2). Diunduh dari: ejournal.unmuha.ac.id/index.php/JAM/article/view/386.

Mafra, Nisa' Ulul, Suhada dan Tri Sinarti. (2018). Kajian Model Empiris Kompetensi Profesional dan Kompetensi Kepribadian Terhadap Motivasi Kerja Serta Implikasinya Pada Kinerja Dosen Universitas Swasta Di Kota Palembang. Jurnal Manajemen dan Bisnis Sriwijaya (JMBS). 16 (2), pp.77-88. Diunduh dari: https //ejournal.unsri.ac.id/ index.php/jmbs/article/view/6941/3457.

Mangkunegara, Anwar, Prabu. AA. (2011). Manajemen Sumber Daya Manusia Perusahaan. Bandung: Penerbit Remaja Rosda Karya.

Peraturan Pemerintah Republik Indonesia Nomor 37 Tahun 2009 tentang Dosen. (2009). Jakarta.

Peraturan Menteri Pendidikan Nasional Republik Indonesia Nomor 47 Tahun 2009 tentang Sertifikasi Pendidik Untuk Dosen. (2009). Jakarta: Kementerian Pendidikan Nasional.

Rivai, Veithzal dan Sagala, Jauvani Ella.(2011). Manajemen Sumber Daya Manusia untuk Perusahaan.Jakarta: PT. Rajagrafindo Persada.

Suhada, Nisa' Ulul Mafra dan Santi Puspita. (2017). Analisis Sertifikasi Dosen dan Motivasi Kerja Terhadap Kepuasan Kerja dan Kinerja Dosen Pada Universitas Swasta di Kota Palembang. Jurnal Media Wahana Ekonomika (JMEW). 14 (2), pp. 1-13. Diunduh dari.https://jurnal.univpgri-palembang.ac.id/index.php/ ekonomika/article/view/1301

Sugiyono. (2017). Metode Penelitian Manajemen. Bandung: Penerbit Alfabeta. 
Trisnaningsih, Sri. (2011). Faktor-Faktor yang Mempengaruhi Kinerja Dosen Akuntansi. Jurnal Akuntansi dan Auditing, 8 (1). Diunduh dari: http//ejournal.undip.ac.id/ index.php/akuditi/article/view/4349

Umar, Husein. (2010). Metodologi Penelitian. Jakarta: Penerbit PT. Raja Grafindo persada.

Undang-Undang No. 12 Tahun 2012 tentang Pendidikan Tinggi. (2012).Jakarta: Kementerian Sekretariat Negara RI.

Undang-Undang Republik Indonesia nomor 14 Tahun 2005 tentang Guru dan Dosen.

Wibowo.(2014). Manajemen Kinerja. Edisi Keempat. Jakarta: PT.Raja Grafindo Persada.

\section{Copyright Disclaimer}

Copyright for this article is retained by the author(s), with first publication rights granted to the journal. 